\title{
Artikkeli
}

\section{Intiimiä journalismia? Diginatiivit mediat ja journalismin mahdollinen tulevaisuus}

\begin{abstract}
Artikkeli käsittelee diskurssianalyysin avulla sitä, miten niin kutsutut diginatiivit mediat merkityksellistävät itseään ja journalismiaan toimintaansa kuvailevilla "about"-sivuillaan. Artikkelissa käsitellään neljää aineistosta tunnistettua diskurssia: identiteettidiskurssi, niche-diskurssi, verkostodiskurssi ja muutosdiskurssi. Diskursseja analysoidaan sosiaalisen median mediaekologian ja keskustelevan journalismiperinteen kontekstissa. Artikkelin keskeinen tulos on, että analysoitujen diginatiivien medioiden käsitys journalismista vastaa keskustelevan journalismin kriteerejä, ja että tämän tyyppisen journalismin voi väittää sopivan "perinteistä" journalismia paremmin internetiin ja sosiaalisen median alustoille. Keskustelevuus viittaa subjektiiviseen tyyliin sekä tulkintojen ja analyysien painottumiseen objektiivisen faktaraportoinnin sijaan tai sen ohella. Nämä puolestaan voivat edesauttaa "intiimin" suhteen muodostumista niin yleisön, toimittajien ja mediaorganisaatioiden kuin yleisön ja maailman tapahtumien välille. Voi ennakoida, että tämän tyyppinen journalismi vahvistuu tulevaisuudessa, ja että diginatiivien medioiden journalismikäsitys edustaa journalismin mahdollista tulevaisuutta.
\end{abstract}

AVAINSANAT: journalismi, sosiaalinen media, diginatiivit mediat, diginatiivi journalismi, median tulevaisuus, tulevaisuudentutkimus.

$\mathrm{T}$ ämä artikkeli tarkastelee journalismin ja median mahdollista tulevaisuutta diginatiivin (digital-native) journalismin ja diginatiivien medioiden käsitteiden kautta. Median ja journalismin tutkimuksessa diginatiiviudella ei viitata Don Tapscottin (1998) diginatiivin sukupolven käsitteeseen. Sen sijaan diginatiivilla journalismilla tarkoitetaan "internetissä syntynyttä", sen arvoihin ja toimintamalleihin kasvanutta journalismia. Diginatiivit mediat ovat puolestaan ensisijaisesti internetissä ja sosiaalisessa mediassa toimivia ja niiden toimintamalleja hyödyntäviä mediaorganisaatioita. 
Vaikka internetillä ei sinänsä ole mitään itsestään selviä arvoja, sillä on oma, muista mediateknologioista poikkeava medialogiikkansa. Tällä tarkoitetaan erityisesti internetiin sopivia toiminta- ja ilmaisutapoja. (Chadwick 2013.) Internet on esimerkiksi aiempia mediateknologioita vuorovaikutteisempi, minkä seurauksena käyttäjät voivat etsiä juuri heitä kiinnostavia uutissisältöjä yhdenmukaisen massauutistuotteen sijaan (van Dijk 2012). Tämä voi puolestaan vaikuttaa journalismiin esimerkiksi siten, että journalistisia sisältöjä aletaan tuottaa yhä enemmän osayleisöille "suuren yleisön" sijaan.

Koska sosiaalinen media on nykyisin keskeinen osa internetiä, sen alustat ovat myös diginatiivin journalismin olennaisia julkaisu- ja toimintaympäristöjä. Samalla nämä alustat vaikuttavat siihen, millaiseksi diginatiivi journalismi muotoutuu. Yksittäisiä palveluita lukuun ottamatta sosiaalisen median vaikutuksia journalismiin on tutkittu vasta vähän (Gulyas 2016). Vaikka tässä artikkelissa ei systemaattisesti käsitellä sosiaalisen median merkitystä journalismin kannalta, sosiaalinen media ymmärretään internetin ohella keskeiseksi osaksi diginatiivien medioiden ja niiden journalismin mediaekologiaa (ks. Tandoc \& Vos 2015).

Diginatiivi-käsitettä on alettu käyttää viime vuosina lähinnä yhdysvaltalaisessa median tulevaisuutta käsittelevässä keskustelussa. (Ks. esim. Jurkowitz 2014; ; Witkin $2013^{2}$; Witschge $2013^{3}$.) Käsite viittaa digitaalisuuden kulttuuriseen, arvoihin ja toimintatapoihin liittyvään ulottuvuuteen. Siksi se soveltuu journalismin muutoksen tarkasteluun paremmin kuin esimerkiksi "verkkomedian" käsite, joka on luonteeltaan neutraalimpi ja teknologialähtöinen. Verkkomedia voi toimia identtisesti perinteisten medioiden kanssa, kun taas "diginatiivi" viittaa jo käsitteenä uusiin toimintamalleihin.

Usein diginatiivit mediaorganisaatiot ovat uusia media-startupeja, mutta eivät välttämättä. Osa on voittoa tavoittelemattomia yrityksiä, ja myös perinteisellä mediayrityksellä voi olla diginatiiveja piirteitä, jos sen arvot ja toimintamallit ammentavat verkon eetoksesta ja käytännöistä. Diginatiiveja medioita on kokonaisuutena tutkittu vielä vähän. Osa tutkimuksista keskittyy tiettyyn yksittäiseen mediaan (Tandoc \& Jenkins 2015; Harbers 2016), osa alueellisiin medioihin (Harlow \& Salaverría 2016), osa paikallisiin ja voittoa tavoittelemattomiin medioihin (Chadha 2015; Ferrucci 2015; Konieczna \& Robinson 2014; Nee 2013) ja osa startup-mediayrityksiin (Carslon \& Usher 2015).

Tässä artikkelissa käsitellään diginatiiveja medioita kokonaisuutena. Tutkimuksen aineisto koostuu diginatiivien mediaorganisaatioiden "about"-sivuista, joilla nämä kuvaavat arvojaan, toimintaansa ja käsitystään journalismista. Aineisto pitää sisällään niin paikallismedioita, startup-yrityksiä, voittoa tavoittelemattomia kuin jo asemansa vakiinnuttaneita diginatiiveja medioita. Aineisto on vinoutunut siinä mielessä, että kaikki mediat ovat englanninkielisiä (yksi on sekä hollannin- että englanninkielinen) ja yhtä lukuun ottamatta kaikki mediat ovat yhdysvaltalaisia. Voi kuitenkin väittää, että yhdysvaltalaiset mediat ovat ainakin länsimaisessa viitekehyksessä yleispäteviä.

Artikkelissa oletetaan, että diginatiivi journalismi poikkeaa perinteisestä journalismista ammattikäytännöiltään, ilmaisutavoiltaan ja journalististen arvojen soveltami- 
seltaan. Näin siksi, että internet eroaa perinteisistä julkaisuympäristöistä ja tarjoaa välineitä uusiin toimintatapoihin. Artikkelissa ei kuitenkaan käsitellä diginatiivia journalismia empiirisenä ilmiönä, vaan diginatiivien medioiden "about"-sivuillaan kuvaamana ideaalityyppinä. On eri asia, miten diginatiivi journalismi käytännössä toteutuu. "About"-sivut soveltuvat hyvin juuri journalististen arvojen ja diskurssien tutkimukseen, sillä niissä mediaorganisaatiot tiivistävät käsityksensä journalismista toimituksellisiksi "manifesteikseen" (Carlson \& Usher 2015).

Artikkelissa pyritäänkin pääsemään käsiksi ennen kaikkea median ja journalismin kulttuuriseen murrokseen: miten journalismi voi muuttua, jos se siirtyy yhä enemmän puhtaasti verkossa toimivaksi. Vielä hahmottuva diginatiivi journalismi nähdään artikkelissa tulevaisuuden journalismin mahdollisena edelläkävijänä ja niin kutsuttuna heikkona signaalina, merkkinä vielä marginaalisesta mutta mahdollisesti vahvistuvasta ilmiöstä (Kuusi \& Hiltunen 2007; Heinonen \& Ruotsalainen 2015). Carlson ja Usher (2015) sekä Nee (2013) esittävätkin, että diginatiivien medioiden toimintamallit, arvot ja käsitykset journalismista voivat yleistyä, kun mediat siirtyvät yhä enemmän verkkoympäristöihin.

Artikkelin tavoitteena on myös tuoda lähinnä angloamerikkalaisissa keskusteluissa käytettyä diginatiivin käsitettä osaksi suomalaista mediatutkimusta. Reuters-instituutin (2016) "Digital News Report 2016" -selvityksen mukaan perinteisen median asema on Suomessa poikkeuksellisen vahva, ja uusia, perinteisiä toimijoita haastavia verkkopohjaisia medioita on täällä vielä vähän. Samalla teknologisen muutoksen ja sosiaalisen median nähdään kuitenkin vaikuttavan vahvasti, joskin vielä jäsentymättömillä tavoilla, myös suomalaiseen journalismiin ja toimittajien työhön (Pöyhtäri ym. 2016). Voikin olettaa, että myös Suomessa nähdään lähitulevaisuudessa yhä enemmän puhtaasti verkossa toimivia ja journalismia uudistavia julkaisuja. Näin yhdysvaltalaiset, diginatiivin journalismin edelläkävijät antavat mallin, josta voidaan ottaa esimerkkiä ja jota voidaan haastaa suomalaista journalismia kehitettäessä.

Artikkelilla on kaksi tutkimuskysymystä: 1) millä diskursseilla diginatiivit mediat merkityksellistävät itseään ja journalismiaan, ja 2) miten diskurssit suhteutuvat sosiaalisen median mediaekologiaan ja keskustelevan journalismin perinteeseen. Näin hahmotetaan, mitä diginatiivi journalismi ja samalla mahdollinen tulevaisuuden journalismi voisivat olla. Tutkimuskysymykseen 1 vastataan osiossa "Diskurssianalyysin tulokset" ja tutkimuskysymykseen 2 osiossa "Johtopäätökset". Näitä ennen seuraavissa kolmessa osiossa käsitellään mediaekologista tutkimusperinnettä, "perinteistä" ja "uutta" journalismia, sekä artikkelin aineistoa ja metodia.

\section{Mediaekologinen tutkimusperinne ja sosiaalisen median julkaisualustat}

Artikkelin lähtökohtana on ajatus, että mediateknologiat eivät ole vain kommunikaatiovälineitä vaan myös elinympäristöjä ja sosiaalisen todellisuuden kasvualus- 
toja. Kulttuuri ja sosiaaliset suhteet luodaan ihmisten välisessä kommunikaatiossa, ja mediateknologiat ohjaavat sitä, mitä voidaan sanoa ja miten. Mediatutkimuksessa tällaista lähestymistapaa kutsutaan mediaekologiseksi. Eri mediateknologiat mahdollistavat erilaista kommunikaatiota, kulttuuria, taloutta sekä erilaisia sosiaalisia suhteita. Mediaekologit jakavatkin usein ihmiskunnan historian kunkin ajan hallitsevan mediateknologian mukaan - esimerkiksi painokoneen aikakaudella viitataan noin 1600-luvulta 1900-luvulle ulottuneeseen tieteellis-teolliseen aikaan. (Hardt 2001; Innis 2007[1950]; McLuhan 1994[1964].)

Internet on tehnyt mediaekologisista näkökulmista ehkä ajankohtaisempia kuin koskaan. Koska internet on interaktiivinen ja mobiililaitteiden myötä kaikkialle sulautunut media, se muistuttaa sitä edeltäneitä medioita enemmän fyysisiä elinympäristöjä (Levinson 2001). Facebookin ja Twitterin kaltaisten sosiaalisten medioiden myötä medioista on tullut "konkreettisia" elinympäristöjä siinä mielessä, että niissä ihmiset voivat tehdä useimpia samoja asioita kuin fyysisessä todellisuudessa. Nathan Jurgensonin (2012) mukaan "virtuaalista" ja "fyysistä" todellisuutta ei pitäisikään ajatella toisistaan erillisinä vaan toisiaan tukevina ja toisiinsa erottamattomasti kietoutuneina.

Internetistä tekee erityisen kommunikaatioteknologian se, että siinä henkilökohtainen ja massaviestintä yhdistyvät. Internetissä kaikki viestintä tapahtuu saman välineen avulla ja samassa ympäristössä. Internet onkin luonut ensimmäistä kertaa kommunikaatioinfrastruktuurin, joka kytkee periaatteessa kaikki yhteiskunnan toimijat ja kommunikaatiotavat toisiinsa. Sosiaaliset, taloudelliset ja mediaverkostot integroituvat internetissä keskenään. (van Dijk 2012, 54-56; Ruotsalainen \& Heinonen 2015.)

Castells (1996, 390-391) kutsuu internetiin liittyvää eri ilmaisumuotojen toisiinsa sulautumista symboliseksi isomorfismiksi. Castellsin mukaan kehitys kytkee eri kokemusmaailmoja ja elämänalueita toisiinsa. Journalismissa tämä voi tarkoittaa sitä, että virallinen, persoonaton standardi- ja asiakieli tekee tilaa subjektiivisemmalle, rikkaammalle ja vapaammalle ilmaisulle. Esimerkiksi Twitterissä toimittajan työ- ja vapaa-ajan identiteetti usein sekoittuvat, minkä lisäksi toimittajien vuorovaikutus ylittää toimialarajoja ja on usein epämuodollista (Barnard 2016).

Kuten johdannossa mainittiin, sosiaalisen median palveluista on tullut yhä tärkeämpiä journalismin jakelu- ja julkaisualustoja (Tandoc \& Vos 2015). Mediaekologisesta näkökulmasta alustojen keskeinen piirre on se, että niissä mediaorganisaatiot toimivat samassa "elinympäristössä" yksilöiden eli yleisönsä kanssa. Sosiaalisen median myötä mediaorganisaatioiden ja niiden yleisön suhteesta voi tulla aiempaa intiimimpi (Beckett \& Deuze 2016), ja yksilöiden elämismaailma onkin yhä vahvemmin läsnä journalismissa. Tämä on alkanut näkyä esimerkiksi siinä, että journalismia tuotetaan vastaamaan yleisön tarpeisiin, mieltymyksiin ja käyttäytymiseen (Welbers et al 2015; Tien Vu 2014). Näistä saadaan tietoa verkkoanalytiikan työkaluilla, seuraamalla sosiaalisen median keskusteluja ja siellä jaettavia sisältöjä (Tandoc 2014), sekä mediaorganisaatioiden ympärille rakentuvien yhteisöjen avulla (Harbers 2016; Malmelin \& Villi 2015). 
Kehityksen seurauksena toimittajat ovat kuitenkin menettäneet perinteistä autonomiaansa. Yksilöt ottavat journalismin portinvartijan roolia paitsi jakamalla sisältöjä verkostolleen myös vaikuttamalla epäsuoraan journalismin agendaan ja sisältöihin. (Tandoc \& Vos 2015; Tien Vu 2014.) Medioiden ja yleisön aiempaa intiimimpi suhde voi kuitenkin uudistaa journalismia viemällä sitä aiempaa dialogisempaan suuntaan. Tätä käsitellään seuraavassa luvussa.

\section{"Perinteisestä" ja "uudesta" journalismista}

Jotta diginatiivien medioiden mukanaan tuomia journalismin mahdollisia muutoksia voi hahmottaa, niiden journalismikäsitystä tulee suhteuttaa "perinteiseen" journalismiin. Tässä artikkelissa perinteisyydellä viitataan journalismin "pitkään linjaan", joka kehittyi 1900-luvulla journalismin ammatillistumisen myötä (Schudson 2001; Soffer 2009; Meyers 2011). Ammatillisen journalismin ytimenä on neutraali faktaraportointi, johon kuuluu oleellisesti ajatus journalismin objektiivisuudesta. Schudsonin (2001) kuvaamista objektiivisuuden keskeisistä piirteistä voi erottaa kolme objektiivisuuden ulottuvuutta: epistemologisen ja ontologisen (journalismi raportoi faktoja ja vain niitä), tyylillisen ja esteettisen (viileä, etäännytetty tyyli), ja käytäntöihin liittyvän (tasapuolisuus, kommentoinnin ja toimittajan omien kehystysten välttäminen).

Perinteiseen journalismiin liittyy myös toimittajille objektiivisuusoletuksen vuoksi suotu status julkisuuden portinvartijoina ja julkisen keskustelun määrittäjinä. Toimittajat arvioivat, mikä tieto on luotettavaa, totuudenmukaista ja julkisesti merkittävää. He suosivat usein lähteinään viranomaisia, poliitikkoja, asiantuntijoita ja eturyhmien edustajia. (Tiffen ym. 2014; Soffer 2009.) Näin perinteiseen journalismikäsitykseen liittyy toimittajien likeinen suhde hallintoon, poliitikkoihin ja muihin eliitteihin. Usein journalismin asialista noudatteleekin näiden tahojen asialistaa (Wahl-Jorgensen ym. 2016; Kantola 2011).

Journalismille voidaan asettaa tiettyjä perusehtoja, jotka pätevät niin perinteisenä pidettyyn kuin tästä poikkeavaan journalismiin. Deuze (2005) esittää, että maasta, mediatyypeistä ja genreistä riippumatta kaikkea journalismia määrittää journalistinen ideologia. Jos ideologian kriteerit eivät täyty, kyse ei ole journalismista vaan jostakin muusta viestinnän muodosta. Deuzen (emt.) mukaan tämä "universaali" journalistinen ideologia koostuu viidestä ydinarvosta:

- Julkinen palvelu: journalistit tuottavat julkista palvelua ja toimivat vallan vahtikoirina

- Objektiivisuus: journalistit ovat puolueettomia, neutraaleja, objektiivisia ja tasapuolisia

- Autonomia: journalistien tulee olla työssään itsenäisiä ja vapaita

- Välittömyys: journalistit tuottavat "uutisia" eli uutta ja ajankohtaista tietoa

- Eettisyys: journalisteilla on "etiikan tajua" ja sen tuomaa legitimiteettiä 
Deuze (2005) korostaa, että arvoja voidaan soveltaa eri tavoin. Toisin sanoen diginatiivi ja muu "uusi" journalismi määrittyvät sen mukaan, miten ne näitä arvoja ja ideaaleja käytännössä toteuttavat. Artikkelin johtopäätöksissä diskurssianalyysin tuloksia reflektoidaan Deuzen (emt.) journalistisen ideologian ydinarvojen "uudelleentulkintoihin".

Edellä esitetyn perusteella voi alustavasti hahmotella, että diginatiivi ja muu "uusi" journalismikäsitys tulkitsee Deuzen (2005) kuvaamaa journalistista ideologiaa uusilla tavoilla, höllentää tyylillisen ja käytäntöihin liittyvän objektiivisuuden (ks. Schudson 2001) vaatimusta, ja laventaa lähteiden ja näkökulmien kirjoa (ks. Agarwal \& Barthel 2015). Voi kuitenkin väittää, että tällöinkään journalismi ei varsinaisesti luo mitään uutta vaan siirtyy hallitsevasta paradigmasta muihin, tähän asti vähemmälle huomiolle jääneisiin suuntauksiin. Muutos voi tapahtua erityisesti vuorovaikutteisuutta, dialogisuutta ja subjektiivisia tyylejä painottavaan suuntaan.

Soffer (2009) pitää objektiivisuutta ja dialogisuutta (sekä tähän liittyvää subjektiivisuutta) yhdysvaltalaisen journalismin keskeisinä, kilpailevina arvoina ja suuntauksina (ks. myös Schudson 2001). Sofferin (2009) jakoa muistuttaen Baym (2016) jakaa journalistiset genret tai diskurssit poliittis-normatiivisiin ja esteettis-ekspressiivisiin. Vastaavantyyppinen jako on yleinen, ja sitä voi soveltaa myös yhdysvaltalaisen journalismin ulkopuolella. Esimerkiksi Kantola (2011) kutsuu 1970-luvulla ja sen jälkeen syntyneitä suomalaisia toimittajia "notkean modernin" journalisteiksi, jotka korostavat toimittajan persoonaa ja läheistä suhdetta yleisöön, kun taas heitä ennen syntyneet "korkean modernin" tai "notkistuvan modernin" journalistit nojaavat etäännytettyyn, objektiivisuutta korostavaan lähestymistapaan.

Niin dialogisen kuin esteettis-ekspressiivisen journalismin käsitteet kyseenalaistavat perinteisen, "objektiivisen" käsityksen journalismista yhdensuuntaisena, hierarkkisena informaation siirtona toimittajilta kansalaisille. Niiden mukaan journalismin tarkoituksena ei ole niinkään mekanistisesti siirtää tietoa yleisölle kuin lisätä heidän subjektiivista ymmärrystään maailmasta. Esteettis-ekspressiiviset ja dialogiset journalismikäsitykset nostavat näin esiin sen, että journalismissa ei ole kyse vain tiedosta, informaatiosta ja rationaalisen päätöksenteon tukemisesta. Niiden lisäksi journalismi kertoo tarinoita, kommunikoi arvoja, antaa äänen eri toimijoille, edustaa identiteettejä ja ihanteita, ja tarjoaa yleisöille affektiivisia kokemuksia. Kuvaamisen ohella journalismi myös luo sosiaalista todellisuutta ja jaettuja kulttuurisia merkityksiä, jo näkökulma- ja aihevalintojensa kautta. (Baym 2016; Carey 1989; Marchionni 2015; Soffer 2009.) Dialoginen journalismiperinne lähtee siitä, että objektiivista totuutta ei voida kokonaan saavuttaa, jolloin journalismi määrittyy useiden, enemmän tai vähemmän subjektiivisten näkemysten väliseksi keskusteluksi; autoritäärisen monologin sijaan tulisi suosia keskustelua ja moniäänisyyttä. Seuraavassa tarkennetaan keskustelevan journalismiperinteen piirteitä ja suhteutetaan sitä internetin ja sosiaalisen median aikaan. 


\section{Journalismin epämuodollistuminen ja keskustelevan journalismin perinne}

Beckett ja Deuze (2016) väittävät, että affektiivisuus, ja samalla subjektiivisuus, korostuvat tulevaisuuden uutismediassa. Näin on Beckettin ja Deuzen mukaan ennen muuta siksi, että yleisöjen elämä on erottamattomasti kietoutunut mediaan. Ihmiset elävät mediassa: jatkuvasti mukana kulkevien mobiililaitteiden kautta uutis- ja muut mediat nivoutuvat yhä vahvemmin ihmisten intiimiin yksityiselämään. Yleisöjen huomiosta kilpailevat uutismedioiden lisäksi lukuisat muut toimijat, ja tällöin journalismin keskeiseksi kysymykseksi nousee yhteyden luominen ja ylläpitäminen sen yleisöihin. Tähän affektiivinen ja subjektiivinen tyyli sopii usein neutraalia ja persoonatonta tyyliä paremmin. (emt.)

Uudet, subjektiivisuutta korostavat normit ja rutiinit näkyvätkin verkkotoimittajien työkäytännöissä. Agarwalin ja Barthelin (2015) mukaan verkkotoimittajat pitävät usein itseään itsenäisinä toimijoina ennemmin kuin uutisorganisaatioiden edustajina, ja asemoivat itsensä perinteisiä uutisorganisaatioita läheisempään suhteeseen yleisönsä kanssa. Perinteisten objektiivisuus- ja neutraaliusnormien sijaan he korostavat henkilökohtaista vastuutaan ja arviointikykyään - tavoitteena on kuvata totuus kuten toimittaja sen ymmärtää, ei niinkään rutiinimaisesti vakiintuneita käytäntöjä noudattaen. Lisäksi perinteisesti journalismiin liitetyn uuden tiedon tuottamisen sijaan verkkotoimittajat korostavat jo olemassa olevan tiedon koostamista, analysointia ja tulkintaa. (emt.) Analyysin ja tulkinnan voi nähdä yrityksenä tarjota yleisölle faktaraportointia kiinnostavampaa journalistista sisältöä.

Uudenlainen, entistä "palvelevampi", interaktiivisempi ja avoimempi yleisösuhde näkyy paitsi verkkotoimittajien työkäytännöissä myös sosiaalisen median alustojen läpileikkaavana eetoksena (Gulyas 2016). Sosiaalisessa mediassa virallinenkin kommunikaatio, kuten poliitikkojen statuspäivitykset, on usein epämuodollista ja "jutustelevaa" (Larsson \& Moe 2011). Jos sosiaalinen media vakiinnuttaa asemansa journalismin keskeisenä julkaisukanavana, epämuodollinen ja keskusteleva tyyli voi yleistyä myös journalismissa (Marchionni 2015; Soffer 2012).

Kuten edellisessä luvussa kävi ilmi, epämuodollisuus, keskustelevuus ja vuorovaikutteisuus eivät ole uusia, internetiin liittyviä journalismin ominaisuuksia. James W. Careyn (1989) mukaan kaikki journalismi tulisi nähdä pohjimmiltaan rituaalisena, kulttuurisena vaihtona ja ihmisten välisenä vuorovaikutuksena - sosiaalisen todellisuuden rakentamisena, ylläpitämisenä ja muuntamisena. Journalismi ei rituaalisen mallin mukaan ole tiedonvälitystä, vaan kommunikaatiota: jakamista, osallistumista ja yhteen liittymistä - yhteisen sosiaalisen todellisuuden luomista (emt., 18-20).

Journalismityyppiä, jossa Careyn kuvailemat ritualistiset piirteet korostuvat, voi kutsua keskustelevaksi journalismiksi (journalism as conversation). Marchionnin (2015) mukaan keskustelevalle journalismille voidaan antaa seuraavat ominaisuudet: 
1) Sosiaalinen läsnäolo (social presence). Toimittajat eivät ole tiedon neutraaleja välityskanavia - journalismi on ihmisten välistä kommunikaatiota ja jaetun todellisuuden luomista.

2) Ystävällisyys (friendliness). Journalistit eivät ole kaikkitietäviä, vaan avoimia kansalaisten ajatuksille, näkemyksille, näkökulmille ja juttuideoille.

3) Epämuodollisuus (informality). Toimittajat käyttävät keskustelevaa, epämuodollista ja ei-luennoivaa tyyliä asiallisen ja etäännytetyn faktaraportoinnin sijaan.

4) Samankaltaisuus (coorientation/homophily). Toimittajat eivät edusta ihmisten yläpuolista instituutiota, vaan ovat yksilöitä muiden yksilöiden joukossa. He jakavat yleisönsä kanssa yhteisiä ominaisuuksia, ja toimittajien tulisi olla yleisönsä kaltaisia.

5) Interaktiivisuus (interactivity). Toimittajat ovat aktiivisessa ja jatkuvassa vuorovaikutuksessa kansalaisten kanssa. Tämä pitää sisällään niin kasvokkaisen vuorovaikutuksen kuin esimerkiksi sähköpostin, sosiaalisen median keskusteIun ja erilaiset kyselyt.

Koska diginatiivit mediat toimivat usein ensisijaisesti sosiaalisen median alustoilla ja näin samassa elinympäristössä yleisönsä kanssa, voi olettaa, että "keskusteleva journalismi" näkyy diginatiivien medioiden journalismikäsityksessä ja itsemäärittelyssä (ks. Marchionni 2015). Langlois'n (2014) kuvaama sosiaalisen median merkityksenannon konteksti muistuttaa medioiden ja yleisön "intiimin" suhteen vuoksi läheisesti keskustelevaa journalismia. Langlois'n mukaan sosiaaliset mediat ovat "merkityskoneita" (meaning machines), jotka tarjoavat käyttäjädatansa perusteella sisältöjä merkitysten, merkityksellisyyden ja identiteetin rakentamisen tarpeisiin. Kytkeytymällä yksilöiden psykososiaaliseen elämismaailmaan ne saavat käyttäjistä yhä tarkempaa henkilökohtaista dataa mainosmyyntiään varten. Mitä enemmän mediaorganisaatiot ja toimittajat toimivat sosiaalisessa mediassa, sitä vahvemmin myös ne oletettavasti omaksuvat sosiaalisen median "merkityskoneiden" toimintalogiikan. Voi olla, että menestyäkseen niiden tulee tuottaa yhä enemmän ihmisten elämismaailmaan kytkeytyvää ja identiteetinrakennusta palvelevaa, eli "keskustelevaa" journalismia.

Tämän artikkelin hypoteesina on, että diginatiivien medioiden esittämä käsitys journalismista toteuttaa keskustelevan journalismin periaatteita sekä noudattaa sosiaalisen median "merkityskoneiden" logiikkaa. Hypoteesit avataan edellä kuvattujen keskustelevan journalismin piirteiden ja Langlois'n (2014) pohjalta seuraaviksi väitteiksi diginatiivien medioiden journalismikäsityksestä. Johtopäätöksissä väitteitä testataan artikkelin tulosten pohjalta. Samalla peilataan sitä, miten diginatiivien medioiden esittämä käsitys journalismistaan toteuttaa Deuzen (2005) kuvaamia journalistisen ideologian ydinarvoja. 
1) Diginatiivit mediat ymmärtävät journalisminsa sellaiseksi, jonka varaan inmiset voivat rakentaa elämänsä merkityksellisyyttä ja jaettua sosiaalista todellisuutta. Ne eivät esitä tuottavansa niinkään objektiivista asiajournalismia kuin yksilöiden elämismaailmasta nousevaa kommunikaatiota.

2) Diginatiivit mediat esittävät itsensä yksilöiden kaltaisiksi ja jakavansa yhteisiä ominaisuuksia yleisönsä kanssa. Näin ne pyrkivät luomaan yleisöönsä intiimin ja henkilökohtaisen suhteen. Tämä merkityksellistää diginatiivien medioiden journalismia tyyliltään epämuodolliseksi ja subjektiiviseksi.

3) Diginatiivit mediat esittävät tuottavansa mahdollisimman laajaa sisältökirjoa. Näin ne uskovat kykenevänsä parhaiten tarjoamaan kullekin käyttäjälle personoituja sisältöjä. Ne esittävät journalisminsa vastaavan yleisön tarpeisiin, joista saadaan tietoa keräämällä käyttäjädataa sekä seuraamalla sosiaalisen median keskusteluja ja osallistumalla niihin.

4) Diginatiivit mediat väittävät tuottavansa uusia ja yllätyksellisiä sisältöjä. Ne pyrkivät vastaamaan henkilökohtaisen transformaation tarpeeseen ja ylläpitävät näin jatkuvan muutoksen eetosta.

5) Diginatiivit mediat esittävät itsensä ja journalisminsa luonteeltaan verkottuneeksi. Ne antavat ymmärtää olevansa aktiivisessa ja jatkuvassa vuorovaikutuksessa eri toimijoiden kanssa.

\section{Aineisto ja metodi}

Artikkelin aineisto koostuu diginatiivien medioiden "about"-sivuista. Näillä sivuilla mediat kuvaavat toimintaansa, arvojaan, journalistisia käytäntöjään ja sisältöjään. Sivut avaavat näkymän siihen, miten diginatiivit mediat ymmärtävät journalismin ja millaisia ominaisuuksia ne itselleen antavat. Samalla avautuu näkymiä journalismin mahdollisiin tulevaisuuksiin. Carlsonin ja Usherin (2015) mukaan "about"-sivut ja muut uusien digitaalisten medioiden "manifestit" määrittelevät tulevaisuuden journalismia tilanteessa, jossa digitaalisen journalismin paradigma ei ole vielä vakiintunut. Samalla "about"-sivu jo itsessään viestii median edelläkävijyydestä ja digitaalisesta eetoksesta. (emt.)

"About"-sivujen tekstit kopioitiin keväällä 2015 yhteiseen tekstitiedostoon. Aineiston pohjana käytettiin Pew-tutkimuslaitoksen listaa suurista digitaalisista uutisorganisaatioista ${ }^{4}$, ja listaa täydennettiin muilla, pienemmillä verkkojulkaisuilla. Aineistossa mukana olevat 36 mediaa ja niiden "about"-sivujen URL-osoitteet löytyvät liitteestä 1. Hollantilaista De Correspondentia lukuun ottamatta kaikki aineiston mediat ovat yhdysvaltalaisia; Business Insiderilla ja Politicolla on toimitus myös Euroopassa.

Vaikka tärkeimpänä medioiden valintakriteerinä oli diginatiivius, medioita valitessa ei edellytetty, että media julkaisee ainoastaan verkossa. Keskeisenä perusteena oli verkkoon keskittyminen ja tavalla tai toisella internetin arvoja ja toimintatapoja ilmentävä kulttuuri - sekä se, että medialla oli oma "about"-sivunsa. "About"-sivu kertoo jo itsessään median pyrkimyksestä uudistaa journalismia ja on tyypillinen verk- 
koon panostaville medioille (Carlson \& Usher 2015). Aineiston medioista Politico ja $n+1$ julkaisevat myös printtilehteä. National Public Radio on puolestaan perinteikäs julkinen media, mutta panostaa vahvasti internetiin ja uusien, diginatiivien ilmaisumuotojen ja toimintatapojen kehittämiseen. Viime vuosina National Public Radio on tullut tunnetuksi suosituista podcasteistaan ja sillä on erillinen digitaalisen yleisön päätoimittajansa sekä digitaalinen uutisosastonsa (NPR Digital News). National Public Radion kohdalla voikin puhua ennemmin ainakin osassa organisaatiosta vallitsevasta diginatiiviuden eetoksesta kuin varsinaisesta diginatiivista mediayhtiöstä.

Medioista Talking Points Memo, GlobalPost ja Quartz kutsuvat itseään diginatiiveiksi (digital native). Vox puolestaan kutsuu yleisöään diginatiiveiksi ("audience of influential digital natives"). Salon kuvailee itseään määreellä "solely-online" ja The Texas Tribune määreellä "digital-first". De Correspondent kutsuu itseään "digitaaliseksi mediaksi" ("a digital medium"), minkä lisäksi kaikki aineiston mediat kertovat tavalla tai toisella olevansa verkkojulkaisuja, tai National Public Radion tapauksessa panostavansa verkkojulkaisemiseen.

Aineistolle tehtiin diskurssianalyysi. Diskurssilla tarkoitetaan yhteiskunnassa tai sen ryhmissä jaettua puhe- ja ymmärrystapaa tietystä asiasta. Diskurssit ohjaavat sitä, miten asioita ja ilmiöitä - kuten journalismia - yhteiskunnassa määritellään ja merkityksellistetään. Samaa asiaa voidaan merkityksellistää usean eri diskurssin kautta, minkä lisäksi diskursseja määritellään jatkuvasti uudelleen. (Fairclough 2003; Hall 1997.)

Koska diginatiivien medioiden käyttämät diskurssit ovat luultavimmin vielä suhteellisen harvinaisia journalismin kentällä, niitä analysoimalla saadaan tietoa siitä, millä uusilla tavoilla journalismi voidaan tulevaisuudessa ymmärtää. Diskurssit käsitetään näin artikkelissa median ja journalismin heikkoina signaaleina - vielä enemmän tai vähemmän marginaalisina mutta tulevaisuudessa mahdollisesti vahvistuvina ilmiöinä ja käsitystapoina.

Diskurssien tunnistaminen aloitettiin hahmottamalla aineistosta toisiaan muistuttavia - esimerkiksi tunteita kuvaavia - sanoja. Sanoista tunnistettiin teemoja ja puhetapoja, jotka merkittiin tekstiin värikoodeilla. Koodatut teemat muodostivat diskurssien aihiot. Varsinainen diskurssianalyysi tehtiin tarkastelemalla sitä, millä tavoin ja mistä näkökulmista teemoja aineistossa esitetään ja merkityksellistetään. Diskurssianalyysin toteutustapa noudattaa Fairclough'n $(2003,129)$ kuvaamaa diskurssianalyysin "perustapaa". Analyysin tarkoituksena on kuvata kulttuuristen merkitysten kautta sitä internetin ja sosiaalisen median kehystämää "sosiaalista todellisuutta" (Berger \& Luckmann 1966), jota aineiston mediat kuvauksissaan journalismista luovat.

Aineistosta tunnistettiin viisi diskurssia: identiteettidiskurssi, niche-diskurssi, verkostodiskurssi, muutosdiskurssi sekä perinteisen journalismin diskurssi. Näiden lisäksi aineistosta tunnistettiin liiketoimintaa ja teknologiaa käsitteleviä teemoja. Koska nämä teemat eivät ole tutkimuksen fokuksessa, ne jätettiin tarkastelun ulkopuolelle, ellei niihin lukeutuvia kohtia voinut perustellusti sisällyttää muihin diskursseihin. Artikkelissa ei kuvata diginatiivia journalismia empiirisenä ilmiönä - tätä varten tarvittaisiin journalististen sisältöjen analyysiä - vaan ennemmin diginatiivien 
medioiden luomana ihanteena. Tutkimuksessa ei niinkään kysytä, mitä diginatiivi journalismi empiirisesti nykyhetkellä on, vaan mitä se diginatiivien medioiden itsemäärittelyn valossa voisi olla.

Perinteisen journalismin diskurssi merkityksellistää journalismia perinteisten, vakiintuneiden journalististen arvojen kautta eli ennen muuta puolueettomana faktojen keräämisenä ja raportoimisena. Koska analyysin tarkoituksena oli tarkastella uusia tapoja, joilla journalismia ja mediaa merkityksellistetään, perinteisen journalismin diskurssi jätettiin analyysin ulkopuolelle. Identiteettidiskurssi on diskursseista määrällisesti hallitsevin 132 tekstiotteella. Niche-diskurssin tekstiotteita on 106, verkostodiskurssin 95 ja muutosdiskurssin 9o. Perinteisen journalismin diskurssin tekstiotteita on 92. On syytä huomata, että "diginatiivi journalismi" on itsessään diskurssi, joka rakentuu eri aladiskursseista. Tässä tutkimuksessa diginatiivin journalismin diskurssia avataan mainittujen neljän aladiskurssin kautta.

\section{Diskurssianalyysin tulokset}

Seuraavassa esitellään neljää aineistosta tunnistettua ja analysoitua diskurssia: identiteettidiskurssi, niche-diskurssi, verkostodiskurssi ja muutosdiskurssi. Englanninkieliset aineisto-otteet on pääosin käännetty suomeksi. Aineiston alkuperäistekstien urlosoitteet löytyvät liitteestä 1.

\section{Identiteettidiskurssi}

Identiteettidiskurssissa mediat merkityksellistävät itseään inmisiin vertautuviksi toimijoiksi, joilla on oma identiteettinsä ja yksilöllisyytensä. Ne rakentavat yksilöiden kaltaista identiteettiään erityisesti antamalla itselleen erilaisia ominaisuuksia ja kuvaamalla "tunteitaan". Esimerkiksi Politico on "ylpeä" ja sillä on "intohimoa". Usein tunteet ja ominaisuudet liittyvät tavalla tai toisella henkilökohtaiseen kiinnostukseen ja uppoutumiseen. Talking Points Memo on "vetoava" ja National Public Radio "merkityksellinen", "uppoutunut", "kekseliäs" ja "intohimoinen". Quartz on puolestaan "luova ja älykäs" sekä "nörttimäinen". Näiden lisäksi Quartzia kuvaavat "pakkomielteet" (obsessions), eli ne aiheet, joihin Quartz erikoistuu.

Arvolähtöisyyden korostaminen on toinen tapa, jolla mediat rakentavat yksilöihin vertautuvaa identiteettiään. Arvolähtöisyys tiivistyy medioiden missioon, niiden toiminta-ajatukseen tai olemassaolon syyhyn. Aineiston medioista 11 kuvaa journalistista toimintaansa "missiona". Missio voi viitata medioiden tehtävään, kuten uutisten selittämiseen Voxilla, "arvopohjaisuuteen", kuten GlobalPostilla, tai yleisiin tavoitteisiin esimerkiksi Texas Tribunen missiona on politiikan läpinäkyvyyden lisääminen.

Medioiden arvolähtöisyys näkyy myös siinä, miten useat mediat esittävät uskovansa asiaansa ja journalismiinsa. Esimerkiksi The Texas Tribune "uskoo intohimoisesti julkiseen mediaan". Asiaansa uskominen viittaa omistautumiseen. Tämä antaa ymmärtää, että mediat välittävät journalismistaan "henkilökohtaisella" tai "tunteelli- 
sella" tasolla. Aineiston medioista yhdeksän kirjoittaakin olevansa omistautunut tai sitoutunut toiminnalleen (dedicated, commitment). Henkilökohtaiseen sitoutumiseen ja kiinnostukseen viittasivat myös edellä mainitut medioiden itselleen antamat luonteenpiirteet, kuten National Public Radion "intohimoisuus". Näin identiteettidiskurssi nivoutuu keskittymistä korostavaan niche-diskurssiin: mediat esittävät keskittyvänsä aiheisiin, joista ne välittävät "henkilökohtaisesti". Tässä voi nähdä yhteyden poliittisiin ja muihin blogeihin, joiden kirjoittajat valikoivat aiheensa usein henkilökohtaisen kiinnostuksen, eivät perinteisten uutiskriteerien perusteella (Klinger \& Svensson 2015).

Identiteettidiskurssissa medioiden toimintaa ohjaa syvä ja koherentti näkemys omasta journalismistaan. Esimerkiksi The Verge kirjoittaa, miten sen missiona on tarjota sisältöjään "yhtenäisesti ja yhdenmukaisesti", ja Gawker siitä, miten se pyrkii luomaan "yhtenäisen vision maailmasta ja sivustostaan". Yhtenäisyys ja yhdenmukaisuus viittaavat siihen, että The Vergellä ja Gawkerilla on vahva toimituksellinen identiteetti, joka näkyy kaikessa niiden sisällöntuotannossa. ProPublica kirjoittaakin suoraan pyrkivänsä luomaan työkulttuurin, jossa sen periaatteet läpäisevät kaiken toiminnan: "Pyrimme luomaan työkulttuurin, jossa toteutetaan kaikkia näitä periaatteita ja jossa periaatteet vaikuttavat kaikkeen, mitä teemme."

Mediat rakentavat identiteettiään myös samastamalla itseään yleisöönsä: mediat esittävät jakavansa yhteisen identiteetin yleisönsä kanssa. Esimerkiksi Mic vertaa itseään nuorten "millenniaalien" sukupolveen kertomalla, että sen lähestymistapa uutisiin on "yhtä uniikki kuin sukupolvemme". Mic kirjoittaa myös suoraan jakavansa "yhteiset ominaisuudet lukijoidemme kanssa".

Mediat voivat samastaa itseään yleisöönsä myös kuvaamalla tämän identiteettiä, ominaisuuksia ja arvoja. Esimerkiksi MinnPost tarjoaa journalismiaan "uutis-intensiivisille, Minnesotasta välittäville ihmisille", ja De Correspondent kuvailee yleisöään "samanmielisten yhteisöksi, ei kohdeyleisöksi". Diskurssissa mediat pyrkivätkin luomaan yleisöönsä samanmielisyyteen perustuvaa ja henkilökohtaista suhdetta. Useat mediat puhuttelevat yleisöään yksilöinä: sinä-pronomini ("you") toistuu aineistossa 47 kertaa. Identiteettidiskurssissa voi nähdä sisäisen ristiriidan: mediat korostavat riippumattomuuttaan, omaehtoisuuttaan ja ainutlaatuisuuttaan, mutta samalla ne paitsi houkuttelevat yleisöä samastumaan itseensä myös itse samastuvat yleisöönsä. Paradoksaalisesti identiteettidiskurssi sekä vahvistaa journalismin tinkimättömän riippumattomuuden arvoa että murentaa perinteisesti ylläpidettyä raja-aitaa medioiden ja yleisön välillä.

Yleisön lisäksi median "persoonaa" voidaan kytkeä inmisiin korostamalla yksittäisiä toimittajia. All Things Digital mainitsee Walt Mossbergin Mossblogin ja The Rumpus päätoimittajansa Stephen Elliottin "yltiöhenkilökohtaisen" uutiskirjeen. The Daily Beast puolestaan julkaisee juttuja "isoilta persoonilta". Yksittäisten toimittajien korostaminen paitsi rakentaa medioiden identiteettiä toimittajapersoonien kautta, myös määrittää journalismia subjektiivisena, toimittajayksilöiden toimintana.

Keskeinen osa identiteettidiskurssia ovatkin henkilökohtaisuus, kommentaarit ja muu mielipiteellinen kirjoittaminen. Kirjoittajan ääni saa kuulua teksteissä, minkä 
voi tulkita tähtäävän juuri median "persoonan" rakentamiseen. Esimerkiksi De Correspondentin journalismi on "kirjoittaja-, ei aihelähtöistä". Tästä syystä sen journalismi on subjektiivista, toimittajien arvojen ja ajatusten ajamaa: "De Correspondentin toimittajat eivät ole objektiivisia 'automaatteja', vaan subjektiivisia, ideoiden ja ihanteiden ajamia yksilöitä." The Marshall Project puolestaan kirjoittaa olevansa "riippumaton mutta ei neutraali media". Diskurssissa journalismi ei siis määrity perinteiseen tapaan "objektiiviseksi". Sen sijaan maailmaa tarkastellaan median ja sen toimittajien yksilöllisistä näkökulmista.

\section{Niche-diskurssi}

Niche-journalismilla viitataan johonkin kapeaan aihealueeseen keskittyvään tai muuten erikoistuneeseen journalismiin. Niche-diskurssissa mediat kuvaavatkin tavalla tai toisella keskittymistä, ja diskurssin usein toistuva sana on "fokus". Fokusoinnin kohteet ovat kuitenkin varsin yleisiä, ja vain harva aineiston media rajautuu johonkin tarkkaan rajattuun nicheen. Esimerkiksi ProPublica keskittyy "oikeasti tärkeisiin tarinoihin, joilla on 'moraalista voimaa'", ja GlobalPost "tärkeisiin liike-elämän, politiikan ja kulttuurin trendeihin".

Tässä voi nähdä yhteyden identiteettidiskurssiin: medioiden "fokus" kuvaa niiden identiteettiä, sitä, mikä erottaa ne muista. Tulkintaa tukee se, että moni media kuvailee toimintaansa sanalla "ydin", "core" - "ydin" liittyy siihen, mikä medialle on ominta. Esimerkiksi GlobalPost kirjoittaa "ydinvahvuuksistaan" ja The Rumpus uskollisuudestaan "ydinajatuksilleen".

Keskittymisen tärkeys näkyy siinäkin, että niche-diskurssiin liittyy vahva syvällisyyden arvo. Sana deep, syvä tai syvällinen, esiintyy eri muodoissaan aineistossa 19 kertaa, ja usein "sukeltamisen" tai "syvälle ulottumisen" merkityksessä: "dive deep" (Pro Publica), "deep dives" (The Awl), "deeper dive" (Texas Tribune), "look deeper" (The Rumpus), "delve deeper" (Vox), "deep-lying" (De Correspondent). Diginatiivien medioiden "nichenä" voi siis tässä mielessä pitää "pintapuolista" ajankohtaisuutisointia tavalla tai toisella syvällisempää ja perehtyneempää journalismia. Keskittyminen ja sen mukanaan tuoma syvällisyys ovat itsessään diskurssissa tärkeitä, ei varsinaisesti tietty keskittymisen tai erikoistumisen kohde. Niche ei määrity niinkään raportoinnin kohteen kuin tyylin ja muodon mukaan. Tästä näkökulmasta niche-journalismi on ennen kaikkea selittävää ja tulkitsevaa, ja suurin osa aineiston medioista kertoo tavalla tai toisella tekevänsä tällaista journalismia.

Selittävä ja tulkitseva journalismi merkitsee aineiston valossa erontekoa perinteisen raportoinnin objektiivisuuteen. Useat aineiston mediat kytkevät selittävän journalismin mielipiteisiin ja kommentaareihin. Esimerkiksi All Things Digital tarjoaa "analyysejä ja mielipiteitä", ja Slate "analyysejä ja kommentaareja". Myös tässä voi nähdä yhteyden identiteettidiskurssiin: diginatiivit mediat tarkastelevat ja tulkitsevat maailmaa omista ja toimittajiensa näkökulmista.

Keskittyminen voi kuitenkin tyylin lisäksi tarkoittaa myös tiettyihin aiheisiin ja aihepiireihin rajautumista. Tässäkin näkyy kuitenkin tietty yleisyys. Moni media mää- 
rittelee nichensä yleisin termein tai usean aihepiirin yhdistelmänä. Esimerkiksi The Awl keskittyy internetilmiöihin, mutta uskoo "ettei ole aihetta, joka ei olisi käsittelemisen arvoinen, kunhan sitä käsitellään kiinnostavasta näkökulmasta". Osa medioista keskittyy journalismin ydinalueisiin, mutta joko tietystä näkökulmasta tai rajautumalla johonkin perinteisen raportoinnin lohkoon. Esimerkiksi MinnPost ja Texas Tribune tuottavat yleisuutisia, mutta paikallisesti ja alueellisesti.

Aihealueet, joihin aineiston mediat erityisesti keskittyvät, ovat teknologia, kulttuuri, talous ja politiikka. Medioista kuusi kirjoittaa teknologiasta, kymmenen kulttuurista, neljä taloudesta ja yksitoista politiikasta. Monet mediat kirjoittavat useammasta kuin yhdestä mainitusta aihealueesta, tai niiden lisäksi muistakin aiheista. Aihealueiden luetteloiminen viestii kuitenkin niche-diskurssille tyypillisestä keskittymisestä ja rajautumisesta - samalla jotain yleisuutispalveluun kuuluvaa jätetään pois.

Aineiston medioista ainoastaan kolme ilmoittaa keskittyvänsä johonkin tai joihinkin hyvin tarkasti rajattuihin niche-alueisiin. The Marshall Project kirjoittaa Yhdysvaltojen rikosoikeusjärjestelmästä. Quartz tarkastelee "uutta globaalia taloutta" fokusoivien "pakkomielteidensä" ("defining obsessions") kautta. Näitä ovat esimerkiksi mobiili internet ja digitaaliset rahayksiköt. Gawker jakaa raportointinsa kymmeneen lohkoon, jotka käsittelevät esimerkiksi Piilaaksoa ja internetkulttuuria, sekä viiteen "henkilökohtaiseen blogiin", jotka muun muassa käsittelevät säätä ja tarkistavat internetin viraalisisältöjen faktoja.

Niche-diskurssin kiinnostava ja yllättäväkin piirre on, että sisältöjen osalta monet aineiston medioista korostavat tuottavansa nimenomaan journalistista yleispalvelua. Niche-diskurssiin nämä otteet on sisällytetty sen vuoksi, että niihin sisältyy jokin tarkentava määre, joka erottaa ne perinteisistä journalismin ja yleisuutisten arvoista. Esimerkiksi Buzzfeed ei julkaise vain uutisia, vaan "jaettavimpia ajankohtaisuutisia" ("the most shareable breaking news").

Syy sille, miksi myös niche-diskurssissa mediat korostavat journalistisen yleispalvelun merkitystä, voi olla taloudellinen. Kaupallisesti toimivat mediat tavoittelevat mahdollisimman suurta yleisöä, ja tällöin yleisjournalismin tarjoaminen voi olla ainoa vaihtoehto. Mahdollisimman suuri sisältökirjo auttaa lisäksi medioita parhaiten kohdentamaan sisältöjä yksilöllisesti kullekin kuluttajalle tai kuluttajaryhmälle. Rajattujen aihealueiden syvällinen tarkastelu puolestaan lupaa kuluttajille perehtynyttä journalismia juuri heitä kiinnostavista aiheista. Diskurssin valossa diginatiivien medioiden "niche-journalismi" on siis yhdistelmä perehtyneitä niche-sisältöjä ja mahdollisimman laajaa sisältökirjoa.

Kun aihepiireillä voi olla taloudellisista syistä vaikea erottautua, eronteko muista medioista tehdään ennen muuta tyylillä ja aiheiden käsittelytavoilla. Voxin päätoimittaja Ezra Klein (20165) kutsuu tätä digitaalisen journalismin keskeiseksi jännitteeksi. Kleinin mukaan menestyneet digitaaliset julkaisut tukeutuvat osin hyviksi havaittuihin yleisiin toimintamalleihin, kuten "populistiseen" suurten yleisöjen palvelemiseen, ja osin kunkin median omille "pakkomielteille, ideoille ja asenteelle". Digitaalisessa maailmassa menestys on Kleinin mukaan sekoitus sitä, "mitä kaikki tekevät" ja "mitä kukaan muu ei tee". 


\section{Verkostodiskurssi}

Verkostodiskurssi merkityksellistää medioita verkoston noodeina tai solmukohtina, ei irrallisina toimijoina. Verkostodiskurssin taustalla voi nähdä verkostoeetoksen, jossa mediat mieltävät itsensä osana suurempaa kokonaisuutta sen sijaan että olisivat tarkkaan rajattuja toimijoita. Tässä voi nähdä eron perinteisiin mediaorganisaatioihin, jotka usein vaalivat rajojaan suhteessa niin yleisöönsä kuin muihin organisaatioihin (Heinrich 2011). Verkostoeetos määrittää niin diginatiivien medioiden yleisösuhdetta kuin journalismin tuotantoa. The Marshall Project kuvailee sivustoaan "dynaamiseksi hubiksi", eli eräänlaiseksi verkoston keskukseksi tai solmukohdaksi. FlavorWire taas on "kulttuurisesti samanhenkisten verkosto".

Yleisösuhteessa verkostoeetos näkyy siinä, miten mediat korostavat niiden ja yleisön välisen vuorovaikutuksen merkitystä. The New Inquiry haluaa "suoran yhteyden yleisöönsä" ja De Correspondent uskoo, että "yleisön aktiivinen mukaan ottaminen on elintärkeää menestyvälle media-alustalle". Kuten identiteettidiskurssissa, myös verkostodiskurssissa mediat pyrkivät luomaan henkilökohtaisen suhteen yleisöönsä. Tämä voi tarkoittaa yksinkertaisesti yhteydenottokehotusta. Esimerkiksi Quartz pyytää lukijoita ottamaan yhteyttä sähköpostitse tai sosiaalisen median kautta.

Korostaessaan suoraa suhdetta yleisöönsä mediat ikään kuin asettavat itsensä samalle tasolle tämän kanssa, mikä näkyy myös läpinäkyvyyden ihanteessa. Mediat eivät esitä itseään suljettuina, vaan avoimina suhteessa yleisöönsä. Quartz haluaa olla "päätöksissään ja suuntavalinnoissaan mahdollisimman läpinäkyvä", ja Gawker on julkaissut "avoimuuden nimissä" sisäisen, päätoimittajansa kirjoittaman suunnittelumuistion.

Tasa-arvoisuutta korostava suhde median ja yleisön välillä tarkoittaa myös "yhdessä tekemistä". Esimerkiksi Gawker on "avoin argumenteille ja taivuttelulle". Tässä verkostodiskurssi kytkeytyy identiteettidiskurssiin. Avoimuuden suhteessa yleisöön voi nähdä keinona, jolla mediat kytkeytyvät yksilöiden elämismaailmaan. Niinpä Rookien syntyä vauhditti päätoimittajan henkilökohtaisessa blogissa esitellyn konseptin saama vastakaiku: "Vastaava päätoimittaja Tavi Gevinson esitteli Rookien idean blogissaan [...] ja sai valtavasti kannatusta". Mic puolestaan sai alkunsa "vuosia kestäneestä ideoiden vaihdosta ystävien kesken".

Verkostoeetoksen mukaisesti myös journalismin konkreettinen tuotanto määrittyy verkostomaiseksi prosessiksi. Kuusi mediaa tuo esiin freelance-verkostonsa ja viisi mainitsee tekevänsä yhteistyötä muiden organisaatioiden kanssa. Esimerkiksi All Things Digital kertoo julkaisevansa tekstejä vierailevilta bloggaajilta, jotka voivat olla niin yritysten edustajia kuin yksittäisiä kirjoittajia.

Medioiden yhteistyö voi olla verkostomaista myös löyhemmin, ei vain konkreettista organisaatioiden välistä yhteistyötä. Pro Publica kirjoittaa, miten se ei ainoastaan julkaise muiden sisältöjä, vaan myös kommentoi ja täydentää niitä. Tämän tavoitteena on paitsi jalostaa muiden tuottamaa sisältöä myös edistää sisältöjen leviämistä ("[se on] keino hyvän raportoinnin edistämiseen"). Tässä voi nähdä avoimen lähdekoodin periaatteista ammentavan ajattelun: journalistin työ rakentuu osin 
muiden jo tekemän työn kommentoimisen, täydentämisen ja avoimen levittämisen varaan.

Avoimen lähdekoodin kehittäjäyhteisöistä muistuttava journalismi ja journalismin verkostomainen tuotanto voivat tarkoittaa myös verkon kollektiivisen älyn valjastamista. Talking Points Memo on "iteratiivisen, lukijoiden tietoa hyödyntävän journalismin pioneeri", ja MinnPost julkaisee "lukijayhteisönsä" kirjoittamia kommentaareja sekä yksittäisten juttujen lukijakommentteja. Rookien sisällöt ovat puolestaan paitsi sen henkilökunnan myös lukijoiden tuottamia.

Verkostodiskurssissa mediat merkityksellistävät itseään monin eri tavoin yhteisöiksi - sana community toistuu diskurssissa 15 kertaa. Yhteisöjen tavoitteena on sitouttaa yleisöä tiiviiksi osaksi mediaa. Esimerkiksi Salon kertoo olevansa "yhteisön sitouttamisen" edelläkävijä. De Correspondent ei kutsu yleisöään "lukijoiksi vaan osallistujiksi" eikä "tilaajiksi vaan jäseniksi". Näin De Correspondent tavoittelee "kestävää ja merkityksellistä suhdetta" yleisöönsä. Yhteisöjen kohdalla näkyy jälleen se, miten aineiston mediat pyrkivät astumaan pois "objektiivisesta" julkisesta sfääristä osaksi yksilöiden elämismaailmaa - yhteisöt tarkoittavat ainakin puheen tasolla, että yleisö otetaan mukaan median toimintaan.

Lopulta verkostodiskurssiin voi tulkita liittyvän kokonaisen maailmankuvan: todellisuus määrittyy siinä verkottuneeksi ja kompleksiseksi. Vox kuvaa käsittelemäänsä aihekirjoa "kompleksiseksi", minkä voi ymmärtää viittauksena kompleksisuusajatteluun. De Correspondent taas kirjoittaa verkostomaisesta maailmankuvasta mainitsemalla, että "yhä globaalimmassa ja verkottuneemmassa" maailmassa aihejako kansallisiin, kansainvälisiin, politiikan ja liike-elämän uutisiin "ei ole enää järkevää". Lainaus antaa ymmärtää, että näennäisesti irrallisten asioiden välisten yhteyksien hahmottaminen on verkottuneessa maailmassa yhä tärkeämpää - sen sijaan että raportoitaisiin yksittäisistä ja näennäisesti irrallisista tapahtumista.

Medioiden uutisoinnissa verkostomainen maailmankuva tarkoittaa myös uutiskriteerien laventamista. Koska mediat eivät aseta uutisagendaa yksin, relevantiksi voi määrittyä periaatteessa mikä tahansa, mitä median verkosto pitää tärkeänä. FlavorWire suosiikin moniarvoisuutta: se julkaisee korkeaa, matalaa ja kaikkea siltä väliltä, kunhan sisältö on "vetoavaa". Vetoavan voi tulkita viittaavan siihen, mitä FlavorWiren yleisö tai verkosto pitää vetoavana. Vastaavasti Thought Catalogin mielestä "kaikki ajattelu on relevanttia"; "ajattelu" viittaa yksilöiden ajatuksiin, ei perinteisiin uutiskriteereihin.

\section{Muutosdiskurssi}

Muutosdiskurssissa diginatiivit mediat asemoivat itsensä muutosvoimiksi: niin yhteiskunnan, median kuin journalismin uudistajiksi. First Look Media esimerkiksi pyrkii "parantamaan yhteiskuntaa journalismin ja teknologian avulla", ja ProPublica haluaa "stimuloida positiivista muutosta" ja saamaan aikaan "reformeja".

Muutospyrkimyksessään diginatiivit mediat eroavat perinteisestä mediasta, joka korostaa rooliaan ennemmin passiivisena tiedonvälittäjänä (Soffer 2009). Vaikka 
yhteiskunnan uudistaminen erityisesti epäkohtia paljastamalla on journalismin perinteisiä tehtäviä, muutosdiskurssi tähtää tätä vahvempaan, aktiivisempaan ja kokonaisvaltaisempaan muutokseen. Esimerkiksi edellisissä lainauksissa mainitut "reformit" tai "yhteiskunnan parantaminen" viestivät sellaisesta aktiivisuudesta, johon harva perinteinen, riippumattomuuttaan korostava media luultavimmin haluaisi ryhtyä.

Perinteinen journalismi voikin muutosdiskurssissa näyttäytyä liian passiivisena suhteessa muutokseen. Mic esimerikiksi kirjoittaa, miten "uutisorganisaatiot voivat tehdä enemmän auttaakseen sukupolveamme toimimaan". ProPublica puolestaan kritisoi perinteistä tutkivaa journalismia sen "epäonnistumisista", millä ProPublica tarkoittaa liian lepsua otetta valtaapitäviin ("Vastaamme tutkivan journalismin ajoittaisiin epäonnistumisiin tutkimalla väärinkäytöksiä sinnikkäästi [...] kunnes muutos saadaan aikaan").

Muutospyrkimys näkyy myös journalistisissa genreissä. Mediat voivat korostaa tarinallisen ilmaisun, ei perinteisen raportoinnin, roolia muutoksen aikaansaamisessa. Myös tässä suhteessa diginatiivit mediat ottavat siis etäisyyttä objektiiviseen, etäännytettyyn journalismiin. Esimerkiksi The Marshall Projectin mukaan "tarinankerronta voi olla voimakas sosiaalisen muutoksen edistäjä". Micin mukaan puolestaan "tarinoilla ja informaatiolla on valtaa muovata maailmaa, erityisesti jos ne haastavat perinteisiä narratiiveja". Tässä "perinteiset narratiivit" voi tulkita viittaavan perinteiseen journalismiin, sillä lainausta edeltävässä kappaleessa Mic kirjoittaa siitä, miten nuorten näkökulma jää usein pois "median narratiivista".

Kuten journalismin konventioista poikkeaminen antaa ymmärtää, yhteiskunnallisten uudistajien lisäksi mediat määrittelevät itseään myös journalismin ja median uudistajiksi. De Correspondent etsii "vaihtoehtoisia tapoja tehdä journalismia". Se määrittelee perinteisen journalismin leimaavaksi piirteeksi median ja yleisön "yksisuuntaisen, yhdeltä monelle" -suhteen, minkä tilalle tarvitaan "yleisön aktiivista mukaanottoa". Politico taas väittää, että "perinteiset journalistiset konventiot" tekevät journalismista "tylsää, ennustettavaa ja usein lukukelvotonta", ja kertoo uudistavansa journalismia rikkomalla nämä konventiot.

Journalismin uudistamisessa voi jälleen nähdä pyrkimyksen kytkeytyä ihmisten elämismaailmaan. De Correspondent avautuu yleisölleen, ja Politico haluaa journalisminsa olevan muuta kuin "tylsää". Journalismin uudistaminen voi tarkoittaa myös sellaisiin tarpeisiin vastaamista, joihin perinteinen journalismi ei tyydyttävästi vastaa. Vox tekee selittävää journalismia, koska perinteinen media ei sitä tarpeeksi tee ("sivusto vastaa selittävän journalismin tyydyttämättömään kysyntään"). The Awl puolestaan väittää, että medioiden tarjoama "uutisruokavalio" on "tylsistyttävän yksipuolinen", ja esittää näin epäsuoraan uudistavansa journalismia laventamalla uutistarjontaa.

Diginatiivi journalismi voikin tarkoittaa uutuuden tarjoamista sinällään. Muutosdiskurssi antaa ymmärtää, että uutuus itsessään on yhä tärkeämpi arvo, ja että myös kuluttajat haluavat entistä enemmän uusia ja tuoreita sisältöjä. Niinpä Vox lupaa lukijoilleen "aiheita, joita he eivät ole tajunneet edes etsiä". GlobalPost puolestaan tarjoaa "tuoreita ja erottuvia" sisältöjä ja Aeon vastauksia, jotka ovat "tuoreita ja omaperäisiä". 
Ajankohtaisuus ja uutuus ovat toki perinteisiä journalistisia arvoja, mutta muutosdiskurssissa uutuus määrittyy ainutlaatuisuutena, sellaisena, mitä muualta ei saa. Uutuus ei siis tässä viittaa digitaalisiin medioihin usein liitettyyn reaaliaikaisuuteen ja nopeaan julkaisutahtiin. Gawker kertoo tarjoavansa uutisia ja näkökulmia, joita "ei mistään muualta saa”. Mic, De Correspondent ja Marshall Report mainitsevat eksplitiittisesti, että ne kirjoittavat aiheista, joita perinteinen media ei käsittele tai joista ei uutisoida tarpeeksi. The Awlin tapaan nämä mediat uudistavat journalismia laajentamalla uutistarjontaa.

Uutuuden tarjoamisen tärkeyttä perustelee osaltaan se, että mediat piirtävät kuvaa nykyisyydestä nopean muutoksen aikana. Muutos liittyy erityisesti teknologiaan ja internetiin. The Awl esimerkiksi korostaa internetin muutosnopeutta kirjoittamalla, miten sen perustamisvuosi 2009 oli "ainakin neljä internetiä sitten". Useat mediat ovat kiinnostuneita nykyisyyden lisäksi myös tulevaisuudesta. Tulevaisuussuuntautuneisuus näkyy puheena trendeistä, tulevaisuutta muovaavista kehityskuluista. Niin Gigaom, Politico kuin GlobalPost kirjoittavat uutisoivansa trendeistä. Lisäksi Gigaom uutisoi "nousevista teknologioista" ja "disruptiivisista yrityksistä". Näin myös Gigaom palauttaa trendit ja yhteiskunnallisen muutoksen erityisesti uusiin teknologioihin ja teknologiayrityksiin.

Lopulta uutuus ja muutos eivät liity vain medioiden arvoihin ja uutistarjontaan vaan koko niiden identiteettiin. Mediat rakentavat itselleen "nykyhetkessä" tai "tässä ajassa" tiukasti kiinni olevaa identiteettiä. Esimerkiksi Quartz kertoo olevansa "tämän ajan ruumiillistuma". Samankaltaista aikalaisanalyyttistä otetta edustavat Aeon, All Things Digital, Thought Catalog ja De Correspondent. Esimerkiksi Thought Catalog kirjoittaa haluavansa "tallentaa tämän ajan huomista varten".

\section{Johtopäätökset}

Yleisesti ottaen diskurssianalyysin tuloksia voi kuvata siten, että ne noudattavat artikkelin hypoteeseja: diginatiivien medioiden käyttämät diskurssit mukailevat keskustelevan journalismin periaatteita ja toteuttavat sosiaalisen median "merkityskoneiden" logiikkaa. Seuraavassa diskurssianalyysin pohjalta testataan Langlois 'n (2014) ja Marchionnin (2015) perusteella muotoiltuja, hypoteeseja avaavia väitteitä diginatiivien medioiden journalismikäsityksestä.

1) Diginatiivit mediat ymmärtävät journalisminsa sellaiseksi, jonka varaan ihmiset voivat rakentaa elämänsä merkityksellisyyttä ja jaettua sosiaalista todellisuutta. Ne eivät esitä tuottavansa niinkään objektiivista asiajournalismia kuin yksilöiden elämismaailmasta nousevaa kommunikaatiota.

Diskursseissa diginatiivit mediat eivät asemoi itseään ulkopuolisiksi, neutraaleiksi tarkkailijoiksi. Niiden itsemäärittely muistuttaa keskustelevan journalismin sosiaalisen läsnäolon kriteeriä, eli sitä, että mediat ja toimittajat nähdään yhteiskunnallisiksi kes- 
kustelijoiksi ja sosiaalisen todellisuuden rakentajiksi, ei passiivisiksi tiedonvälityskanaviksi. Esimerkiksi De Correspondent kertoo journalisminsa olevan toimittajien arvojen ja ideaalien ajamaa, ja moni media korostaa avointa, kommunikatiivista suhdetta yleisöönsä.

Voi väittää, että tämän kaltainen subjektiivisuutta ja kommunikaatiota korostava journalismi auttaa etäännytettyä ja objektiivista journalismia paremmin yksilöitä rakentamaan elämänsä merkityksellisyyttä ja luomaan heidän välilleen jaettua sosiaalista todellisuutta. Harbersin (2016) mukaan etäännytetystä positiosta luopuva journalismi kykeneekin tätä paremmin sitouttamaan yleisöä, eli vetoamaan tähän tavalla tai toisella henkilökohtaisella tasolla. Jos sosiaaliset mediat nähdään Langlois'n (2014) tapaan ennen muuta identiteetin rakentamisen välineiksi, diginatiivien medioiden oletettu "identiteettijournalismi" sopii näille alustoille hyvin.

2) Diginatiivit mediat esittävät itsensä yksilöiden kaltaisiksi ja jakavansa yhteisiä ominaisuuksia yleisönsä kanssa. Näin ne pyrkivät luomaan yleisöönsä intiimin ja henkilökohtaisen suhteen. Tämä merkityksellistää diginatiivien medioiden journalismia tyyliltään epämuodolliseksi ja subjektiiviseksi.

Diskurssianalyysin perusteella diginatiivit mediat esittävät rakentavansa itselleen muista erottuvaa, yksilöllistä persoonallisuutta. Usein identiteettiä väitetään rakennettavan suhteessa median yleisöön. Esimerkiksi Mic kertoo jakavansa samat ominaisuudet lukijoidensa kanssa. Tässä on suora yhteys keskustelevan journalismin samankaltaisuus-kriteeriin, eli siihen, että medioiden ja toimittajien tulisi olla yleisönsä kaltaisia.

Fairclough'n (1997) mukaan toimittajien persoonan korostaminen pyrkii usein siihen, että media jakaisi yleisönsä identiteetin ja elämismaailman. Persoonallisuuden rakentamisen tavoitteeksi voikin tulkita tiettyyn yleisösegmenttiin vetoavan tyylin ja identiteetin, mikä puolestaan edesauttaa henkilökohtaisen, intiimin tai sitoutuneen yleisösuhteen luomista. Diginatiivien medioiden pyrkimys kytkeytyä ihmisten elämismaailmaan on keskeinen, diskursseja yhdistävä teema, ja tämä edellyttää medialta samastuttavaa "persoonaa".

Diskurssianalyysin perusteella oletettu diginatiivi journalismi nousee inmisten elämismaailmasta kahdella tavalla. Ensinnäkin, jos mediat tuottavat journalismia "persoonina", tarkoittaa tämä yksilöllisen elämismaailman läsnäoloa journalismissa. Diginatiivien medioiden journalismi ei perinteiseen tapaan lukeutuisi selvästi "objektiiviseen" julkiseen sfääriin, ja toimittajat voisivat kirjoittaa omalla, epämuodollisellakin tyylillään. Myös "about" -tekstit ovat itsessään usein tyyliltään epämuodollisia. Näissä näkyy keskustelevan journalismin epämuodollisuus-kriteeri. Toisekseen aineiston medioiden korostama avoimuus ja vuorovaikutteisuus voivat toteutuessaan auttaa kytkemään yksilöiden elämismaailmaa medioihin. Esimerkiksi Rookie kirjoittaa, miten sen syntyä vauhditti päätoimittajan henkilökohtaisessa blogissa esitellyn konseptin saama vastakaiku. Tämä ilmentää keskustelevan journalismin interaktiivisuus- ja ystävällisyys-kriteerejä. 
3) Diginatiivit mediat esittävät tuottavansa mahdollisimman laajaa sisältökirjoa. Näin ne uskovat kykenevänsä parhaiten tarjoamaan kullekin käyttäjälle personoituja sisältöjä. Ne esittävät journalisminsa vastaavan yleisön tarpeisiin, joista saadaan tietoa keräämällä käyttäjädataa sekä seuraamalla sosiaalisen median keskusteluja ja osallistumalla niihin.

Diskursseissa korostuvat niin laveat uutiskriteerit kuin laaja sisältö- ja tyylikirjo. Aineiston mediat painottavat käsittelevänsä periaatteessa mitä tahansa - esimerkiksi The Awl kirjoittaa, ettei ole aihetta, joka ei olisi käsittelemisen arvoinen. Toisaalta mediat korostavat keskittymisen ja fokusoinnin tärkeyttä.

Laajaa uutiskirjoa yhtäällä ja keskittymistä toisaalla voi tulkita nimenomaan yleisön tarpeisiin vastaamisena. Jotta mediat voisivat vastata kysyntään, niiden on oltava valmiita käsittelemään aihetta kuin aihetta. Jotta käsittely toisaalta olisi kiinnostavaa, medioiden on käsiteltävä aiheita perehtyneesti ja keskittyen. Tässä voi nähdä yhteyden keskustelevan journalismin ystävällisyys-kriteeriin, joka korostaa toimittajia kansalaisten "palvelijoina".

Aineiston mediat eivät suoraan mainitse seuraavansa yleisön valintoja, käyttäytymistä ja sosiaalisen median keskusteluja, mutta diskursseissa korostuva yleisön tarpeisiin vastaaminen perustelee tämän tyyppistä toimintaa. Jos oletuksena on, että diginatiivit mediat pyrkivät tuottamaan yleisönsä elämismaailmaan sopivaa journalismia, yleisön seuraaminen eri tavoin voi olla jopa edellytys niiden journalismille. Marchionnin (2015) mukaan journalismin "ystävällisyyteen" kuuluu yleisön kuunteleminen, ja sosiaalisen median aikana tämän voi tulkita tarkoittavan yhä enemmän yleisön "mittaamista" ja sosiaalisen median keskustelujen seuraamista sekä niihin osallistumista.

4) Diginatiivit mediat väittävät tuottavansa uusia ja yllätyksellisiä sisältöjä. Ne pyrkivät vastaamaan henkilökohtaisen transformaation tarpeeseen ja ylläpitävät näin jatkuvan muutoksen eetosta.

Diskurssianalyysiin perusteella diginatiivit mediat väittävät tarjoavansa uutuutta. Esimerkiksi Gawker kertoo tarjoavansa uutisia, joita ei mistään muualta saa. Uutuuden tarjoamisen voi nähdä keskustelevan journalismin ystävällisyys-kriteerin ilmauksena, jos sillä pyritään vastaamaan tyydyttämättömään kysyntään.

Uutuusarvon korostamiselle voi tulkita neljä keskeistä syytä. Ensinnäkin, koska diginatiivit mediat oletetusti tarjoavat journalismia, jonka avulla yksilöt voivat rakentaa identiteettiään, tarvitaan jatkuvasti uusia ja yllättäviä sisältöjä ja näkökulmia. Identiteetin rakentaminen on jatkuva prosessi ja vaatii alati uusia aineksia. Toiseksi omaperäiset sisällöt auttavat medioita erottumaan muista, mikä on yhä tärkeämpää sosiaalisen median sisältövirroissa. Kolmanneksi diginatiivit mediat esittävät journalisminsa kuvaavan nopeasti muuttuvaa yhteiskuntaa, sen keskeisiä ilmiöitä ja kehityskulkuja - siis "uutuutta". Neljänneksi diginatiivit mediat tuottavat sisältöjä sosiaalisen median jatkuvasti päivittyvään uutisvirtaan, mikä itsessään korostaa jat- 
kuvan uutuuden vaatimusta. Näistä syistä voi olettaa, että diginatiivit mediat tukevat sosiaaliseen mediaan liittyvää dynaamisuutta, uutuutta ja muutosta korostavaa kulttuuria.

5) Diginatiivit mediat esittävät itsensä ja journalisminsa luonteeltaan verkottuneeksi. Ne antavat ymmärtää olevansa aktiivisessa ja jatkuvassa vuorovaikutuksessa eri toimijoiden kanssa.

Diskurssianalyysin perusteella diginatiivit mediat esittävät olevansa verkottuneita niin freelance-toimittajien kuin muiden medioiden ja organisaatioiden kanssa. Aineiston mediat antavat myös ymmärtää ottavansa yleisöä mukaan uutistuotantoon. Voikin väittää, että diginatiiveja medioita määrittää yhteistyötä ja jakamista korostava verkostoeetos. Journalismin tuotanto määrittyy kollektiiviseksi, verkostomaiseksi prosessiksi, jota mediat eivät enää yksin hallitse. Myös aihevalinnat ja uutisagendan asettaminen voivat siirtyä osittain medioiden ulkopuolelle, ja relevantiksi voi määrittyä periaatteessa mikä tahansa, mitä median verkosto pitää tärkeänä. Tämä kytkee diginatiivit mediat keskustelevan journalismin interaktiivisuus- ja ystävällisyys-kriteereihin.

Verkostoeetoksen voi tulkita liittyvän siihen, että sosiaalisen median verkottuneet ja vuorovaikutteiset alustat ovat diginatiivien medioiden keskeisiä julkaisukanavia. Alustoilla sisältöjen leviämistä edistää, jos ne ovat jo lähtökohtaisesti enemmän tai vähemmän verkoston tuottamia - toisin sanoen kytkeytyneet yleisön elämismaailmaan (ks. Jenkins ym. 2013). Tämä puolestaan kyseenalaistaa medioiden perinteisesti varjelemaa riippumattomuutta ja autonomiaa.

Diginatiivien medioiden diskursseissa hahmottuvan journalismikäsityksen tarkentamiseksi seuraavassa käsitellään vielä lyhyesti, miten diskurssianalyysin tulokset suhteutuvat seuraaviin journalistisen ideologian ydinarvoihin ja Deuzen (2005) tulkintoihin niistä: julkinen palvelu, objektiivisuus, autonomia ja välittömyys. Artikkelin päättävässä pohdintaluvussa vedetään yhteen, millaista diginatiivien medioiden "uusi" journalismi toteutuessaan voisi olla.

Julkinen palvelu: journalistit tuottavat julkista palvelua ja toimivat vallan vahtikoirina. Deuzen (2005) mukaan journalismin julkinen palvelu voi tarkoittaa vallan vahtikoira -roolin lisäksi yhä enemmän yleisölähtöistä, eri osayleisöjä palvelevaa journalismia. Diskurssianalyysin valossa tämä pätee myös diginatiiveihin medioihin. Ne antavat ymmärtää suuntaavansa journalisminsa massayleisön sijaan osayleisöille.

Objektiivisuus: journalistit ovat puolueettomia, neutraaleja, objektiivisia ja tasapuolisia. Deuze (2005) esittää, että journalismin "uusi objektiivisuus" pitää sisällään yhä enemmän toimittajien kommentteja ja kannanottoja sekä korostaa julkisen keskustelun merkitystä ylhäältä annetun totuuden sijaan. Diginatiivit mediat esittävät objektiivisuuden juuri näin: ne väittävät pitävänsä kiinni totuuden ideaalista, mutta samalla korostavat toimittajien aktiivista kommentointia ja tiedon omaehtoista arviointia. 
Autonomia: journalistien tulee olla työssään itsenäisiä ja vapaita. Deuzen (2005) mukaan perinteinen autonomiakäsitys voi eristää toimittajat liiaksi muista yhteiskunnan toimijoista ja ehkäistä toimittajien vuorovaikutusta yleisönsä kanssa. Diginatiivit mediat esittävät itsensä yhtä lailla itsenäisinä kuin verkottuneina toimijoina. Ne kuvaavat itseään "yksilöllisesti" autonomisina ennemmin kuin muista toimijoista eristyneinä. Tämä heijastelee Agarwalin ja Barthelin (2015) tulosta, jonka mukaan verkkotoimittajat korostavat samaan aikaan yksilöllistä, eivät niinkään journalismiinstituutioon liitettyä itsenäisyyttä, ja läheistä suhdetta yleisöönsä.

Välittömyys: journalistit tuottavat "uutisia" eli uutta ja ajankohtaista tietoa. Journalismin perustehtävä on tuottaa uutta tietoa, ja internetin myötä kilpailu uutuudesta on tihentynyt ympärivuorokautiseksi 24/7-julkaisemiseksi (Deuze 2005). Vaikka diginatiivit mediat esittävät tuottavansa myös uutta ajankohtaistietoa, niiden ymmärrys "uutuudesta" muistuttaa Agarwalin \& Barthelin (2015) kuvaamaa verkkotoimittajien käsitystä: uutuutta eivät määritä niinkään ajankohtaisuutisten kriteerit kuin ainutlaatuisuus ja uutuus tietylle osayleisölle. Näin uutuuden tuottaminen tarkoittaa usein raportoinnin sijaan jo raportoidun tulkintaa ja kontekstualisointia.

\section{Pohdintaa: "Intiimiys" journalismin mahdollisena tulevaisuutena}

Artikkelin tulosten perusteella diginatiivi journalismi voisi painottua objektiivisen sijaan dialogiseen (Soffer 2009; Marchionni 2015) ja esteettis-ekspressiiviseen (Baym 2016) journalismisuuntaukseen. Koska objektiivisuutta korostava journalismiperinne on edelleen hallitseva (Schudson 2001; Reunanen \& Koljonen 2014; Meyers 2011), diskurssit antavat olettaa, että yleistyessään diginatiivi journalismi ohjaisi journalismin valtavirtaa dialogiseen ja esteettis-ekspressiiviseen suuntaan. Tätä olisi niiden luoma "uusi" journalismi. Kyseessä on yksi journalismin mahdollinen tulevaisuus.

Koska diginatiivit mediat esittävät olevansa yleisönsä kaltaisia ja vuorovaikutteisessa suhteessa tähän, diginatiivia journalismikäsitystä voi diskurssianalyysin perusteella kutsua "intiimiksi journalismiksi" (ks. Harrington 1997). Journalismin tutkimuksessa "intiimiydellä" on viitattu muun muassa tunnustukselliseen, toimittajan tai yleisön henkilökohtaista elämää käsittelevään journalismiin ja tähän liittyvään yksityisen ja julkisen raja-aidan hälventymiseen (Harrington 1997; Coward 2010), kaunokirjallisia tyylikeinoja hyödyntävään journalismiin (Zdvoc 2007), selittävään, narratiiviseen ja yleisöä mobilisoivaan hitaaseen journalismiin (Neveu 2016), feature-journalismin subjektiivisiin, henkilökohtaisiin ja emotionaalisiin painotuksiin (Steensen 2009), sekä siihen, että internetjournalismiin sopivat hyvin "intiimin keskustelun" piirteet (Barnes 2014). Beckett ja Deuze (2016) nostavat puolestaan esiin sen, että suhteemme mobiiliteknologian välittämään mediaan on muodostumassa yhä intiimimmäksi, ja että tämä korostaa sitouttamisen (engagement) ja affektien merkitystä journalismissa. 
Kaikki mainitut esimerkit viittaavat tavalla tai toisella siihen, että "intiimin" journalismin tavoitteena on tuoda tapahtumat ikään kuin lähemmäksi lukijaa, tehdä niistä subjektiivisesti todellisia. Harrington (2003) nostaakin "intiimin journalismin" keskeiseksi määreeksi tapahtumien ja ilmiöiden subjektiivisten merkitysten tavoittamisen. Voi olla, että tämän tyyppinen journalismi sopii etäännytetyn objektiivisuuden "perinteistä" journalismia paremmin sosiaalisen median aikaan, jossa korostuu medioiden ja yleisön aiempaa suorempi ja vuorovaikutteisempi suhde (Gulyas 2016; Jenkins ym. 2013).

Samalla tämä vielä hypoteettinen diginatiivi, intiimi journalismi voi kytkeä yleisöä objektiivisen perinteen journalismia tiiviimmin maailman tapahtumiin ja auttaa ymmärtämään ja merkityksellistämään maailmaa tätä paremmin (Wahl-Jorgensen 2013). Tähän tiivistyy diginatiivin journalismin lupaus journalismin kehittämisestä: kuinka tehdä journalismista yleisöille aiempaa kiinnostavampaa ja merkityksellisempää sekä todellisuuden laadulliset piirteet paremmin tavoittavaa (Harbers 2016; Beckett \& Deuze 2016). The New York Times nostikin Donald Trumpin presidentinvaalivoiton jälkeen esiin sen, että valtavirtajournalismi ei kyennyt ymmärtämään Yhdysvaltojen poliittisessa ja sosiokulttuurisessa ilmapiirissä tapahtunutta laadullista muutosta. Samalla lehti väitti, että myös sen edustama journalismi on "perustavanlaatuisesti rikki", ja että myös valtamedioiden täytyy harkita nykyistä vuorovaikutteisempaa ja kantaaottavampaa, sosiaalisen median alustoille sopivaa journalismia. (Rutenberg 2016; Herrman 2016.)

Diginatiivi journalismi vaatii vielä empiiristä tutkimusta - erityisesti sen suhteen, miten diginatiivien medioiden diskurssit käytännössä näkyvät niiden journalismissa ja myös journalismissa ylipäätään. Samalla tarvitaan lisää maakohtaista tutkimusta. Lisäksi tarvitaan lisää empiiristä tutkimusta siitä, miten vuorovaikutuksen, verkostomaisen autonomian ja subjektiivisten näkökulmien korostuminen käytännössä suhteutuvat journalismin riippumattomuuden, faktuaalisuuden ja julkisen palvelun arvoihin (van Zoonen 2012; Deuze 2005).

Subjektiivisten, toimittajan omien näkemysten korostumisessa on vaarana, että "henkilökohtainen" totuus nousee "objektiivisen" totuuden yli (van Zoonen 2012), jolloin tuloksena voi olla "faktojen jälkeinen" aika (Manjoo 2008). Tässä kohden täytyy kuitenkin muistaa, että Deuzen (2005) kuvaamien journalismin perusarvojen ja -kriteerien mukaan tällainen viestintä ei olisi enää journalismia, minkä lisäksi myös objektiivinen journalismi väistämättä rakentaa todellisuutta näkökulmien, lähteiden ja aiheiden valinnalla. Journalismin objektiiviset ja subjektiiviset elementit eivät suljekaan toisiaan pois (van Zoonen 1998).

Subjektiivisuutta ja objektiivisuutta painottavien genrejen yhdistelmistä voi tulevaisuudessa nousta uudenlaisia journalistisia hybridejä (Baym 2016). Beckett ja Deuze (2016) kutsuvat "affektiivisia tyylikeinoja" hyödyntävää mutta journalismin kriteereistä kiinni pitävää journalismia "affektiivisen objektiivisuuden" hybridijournalismiksi. "Affektiivinen objektiivisuus" voi tarkoittaa esimerkiksi sitä, että toimittaja raportoimisen lisäksi myös arvioi tietoja itsenäisesti - esittää arvostelmia, tulkitsee ja tuo esiin aiheeseen liittyviä affektiivisia näkemyksiä (Wahl-Jorgensen 2013). Jos journalismi on modernin ajan keskeinen "itseymmärryksen" ja "käsittämisen" käytäntö (sense-making 
practice of modernity) (Hartley 1996), tässä artikkelissa hahmoteltu diginatiivi journalismi voikin toteutuessaan ja yleistyessään uudistaa journalismin valtavirtaa ennen kaikkea sen sense-making-käytäntöjä uudistamalla.

\section{Viitteet}

1 Jurkowitz, Mark (2014). How Big Is the Digital News World? http://www.journalism.org/2014/03/26/ how-big-is-the-digital-news-world/ (Luettu 21.4.2016)

2 Witkin, Kira (2013). Startup InsideClimate News' Pulitzer marks a 'score' for digital-native journalism. http://blog.wan-ifra.org/2013/o4/17/startup-insideclimate-news-pulitzer-marks-a-score-for-digitalnative-journalism (luettu 20.4.2016)

3 Witschge, Loes (2013). A Dutch crowdfunded news site has raised $\$ 1.3$ million and hopes for a digitalnative journalism. http://www.niemanlab.org/2013/o4/a-dutch-crowdfunded-news-site-has-raised-13-million-and-hopes-for-a-digital-native-journalism/ (luettu 20.4.2016)

4 Jurkowitz, Mark (2014). How Big Is the Digital News World? http://www.journalism.org/2014/03/26/ how-big-is-the-digital-news-world/ (Luettu 21.4.2016)

5 Klein, Ezra (2016). The New Republic is up for sale, but what is its next owner buying? http://www vox.com/2014/12/4/7337491/new-republic-changes (luettu 20.4.2016)

\section{Kirjallisuus}

Agarwal, Sheetal D. \& Barthel, Michael L. (2015). The friendly barbarians: Professional norms and work routines of online journalists in the United States. Journalism, 16:3, 376-391.

Barnard, Stephen R. (2016). 'Tweet or be sacked': Twitter and the new elements of journalistic practice. Journalism, 17:2, 190-207.

Barnes, Renee (2014). The "ecology of participation". Digital Journalism, 2:4, 542-557, DOI: $10.1080 / 21670811.2013 .859863$

Baym, Geoffrey (2016). Journalism and the hybrid condition: Long-form television drama at the intersections of news and narrative. Journalism, DOI: 10.1177/1464884916657521. Article in press.

Becket, Charlie \& Deuze, Mark (2016). On the role of emotion in the future of journalism. Social Media + Society, July-September 2016, 1-6.

Berger, Peter \& Luckmann Thomas (1966). The Social Construction of Reality: A Treatise in the Sociology of Knowledge. New York: Anchor Books.

Carey, James W. (1989). Communication as Culture: Essays on Media and Society. New York: Routledge.

Carlson, Matt \& Usher, Nikki (2015). News startups as agents of innovation. Digital Journalism, DOI: $10.1080 / 21670811.2015 .1076344$

Castells, Manuel (1996). The Rise of the Network Society. The Information Age: Economy, Society and Culture Vol. I. Oxford: Blackwell.

Chadha, Monica (2015). What I am versus what I do. Journalism Practice, DOI: 10.1080/17512786.2015.1046994

Chadwick, Andrew (2013). The Hybrid Media System. Politics and Power. Oxford: Oxford University Press.

Coward, Rosalind (2010). Practice review: journalism ethics and confessional journalism. Journalism Practice, 4:2, 224-233, DOI: $10.1080 / 17512780903523142$

Deuze, Mark (2005). What is journalism? Professional identity and ideology of journalists reconsidered. Journalism, 6:4, 442-464, DOI: 10.1177/1464884905056815

Dijk, Jan van (2012). The Network Society. London: Sage Publications.

Fairclough, Norman (2003). Analysing Discourse. Textual Analysis for Social Research. New York: Routledge.

Fairclough, Norman (1997). Miten media puhuu. Tampere: Vastapaino.

Ferrucci, Patrick (2015). Public journalism no more: The digitally native news nonprofit and public service journalism. Journalism, 16:7, 904-919. DOI: 10.1177/1464884914549123

Gulyas, Agnes (2016). Hybridity and social media adoption by journalists. Digital Journalism, DOI: $10.1080 / 21670811.2016 .1232170$ 
Hall, Stuart (toim.) (1997). Representation: Cultural Represenations and Signifying Practices. London: Sage Publications.

Harbers, Frank (2016). Time to engage. Digital Journalism, DOI: 10.1080/21670811.2015.1124726

Hardt, Hanno (2001). Social Theories of the Press. Constituents of Communication Research, 1840s to 1920 . Second Edition. Lanham: Rowman \& Littlefield Publishers, INC.

Harlow, Summer \& Salaverría, Ramón (2016). Regenerating journalism. Digital Journalism, DOI: $10.1080 / 21670811.2015 .1135752$

Harrington, Walt (2003). What journalism can offer ethnography. Qualitative Inquiry, 9:1, 90-104, DOI: 10.1177/1077800402239342

Harrington, Walt (1997). A writer's essay: Seeking the extraordinary in the ordinary. Teoksessa Harrington, Walt (toim.) (1997). Intimate Journalism: The Art and Craft of Reporting Everyday Life, xvii- xxvi. Thousand Oaks: Sage.

Hartley, John (1996). Popular Reality: Journalism, Modernity and Popular Culture. London: Arnold.

Heinonen, Sirkka \& Ruotsalainen, Juho (2015). KUDOS - Median ja journalismin viriäviä tulevaisuuksia. Tutu eBook 4/2015. Tulevaisuuden tutkimuskeskus, Turun yliopisto. http://www.utu.fi/fi/yksikot/ffrc/ julkaisut/e-tutu/Documents/eTutu_4-2015.pdf

Heinrich, Ansgard (2011). Network Journalism. Journalistic Practice in Interactive Spheres. New York : Routledge.

Herrman, John (2016). Online, everything ss alternative media. The New York Times, 11.11.2016.

Innis, Harold A. (2007 [1950]). Empire and Communications. Toronto: Dundurn Press Limited.

Jenkins, H.; Ford, S.; Green, J. (2013). Spreadable Media. Creating Value and Meaning in a Networked Culture. New York: New York University Press.

Jurgenson, Nathan (2012). When atoms meet bits: Social media, the mobile web and augmented revolution. Future Internet, 4, 83-91.

Jurkowitz, Mark (2014). The Growth in Digital Reporting. What it Means for Journalism and News Consumers. http://www.journalism.org/files/2014/o3/Shifts-in-Reporting_For-uploading.pdf

Klinger, Ulrike \& Svensson, Jakob (2015). The emergence of network media logic in political communication: A theoretical approach. New Media Q Society, 17:8, 1241-1257, DOI: 10.1177/1461444814522952

Konieczna, Magda \& Robinson, Sue (2014). Emerging news non-profits: A case study for rebuilding community trust? Journalism, 15:8, 968-986, DOI: 10.1177/1464884913505997

Kantola, Anu (2011). Notkean journalismin nousu. Teoksessa: Kantola, Anu (toim.) (2011). Hetken hallitsijat. Julkinen ellämä notkeassa yhteiskunnassa. Helsinki: Gaudeamus University Press.

Kuusi, Osmo \& Hiltunen, Elina (2007). The Signification Process of the Future Sign. FFRC eBook 4/2007, http:// www.utu.fi/fi/yksikot/ffrc/julkaisut/e-tutu/Documents/eTutu_2007-4.pdf

Larsson, Anders Olof \& Moe, Hallvard (2011). Studying political microblogging: Twitter users in the 2010 Swedish election campaign. New Media Q Society , 14:5, 729-747.

Levinson, Paul (2001). Digital McLuhan.A Guide to the Information Millennium. New York: Routledge.

Malmelin, Nando \& Villi, Mikko (2015). Audience community as a strategic resource in media work. Journalism Practice, DOI: 10.1080/17512786.2015.1036903

Manjoo, Farhad (2008). True Enough: Learning to Live in a Post-fact Society. Hoboken: Wiley.

Marchionni, Doreen (2015). Journalism-as-a-conversation: An experimental test of sociopsychological/ technological dimensions in journalist-citizen collaborations. Journalism, 16:2, 218-237.

McLuhan, Marshall (1994 [1964]). Understanding Media. The Extensions of Man. Massachusetts: The MIT Press.

Meyers, Oren (2011). Expanding the scope of paradigmatic research in journalism studies: The case of early mainstream Israeli journalism and its discontents. Journalism, 12:3, 261-278.

Nee, Rebecca Coates (2013.) Creative destruction: an exploratory study of how digitally native news nonprofits are innovating online journalism practices. International Journal on Media Management, 15:1, 3-22, DOI: $10.1080 / 14241277.2012 .732153$

Neveu, Erik (2016). On not going too fast with slow journalism. Journalism Practice, 10:4, 448-460, DOI: $10.1080 / 17512786.2015 .1114897$.

Pöyhtäri, Reeta \& Väliverronen, Jari \& Ahva, Laura (2016). Suomalaisen journalistin itseymmärrys muutosten keskellä. Media Q viestintä, 39:1, 1-23.

Reunanen, Esa \& Koljonen, Kari (2014). Toimittajan sanansijat. Tampere: Tampere University Press.

Reuters Institute (2016). Digital News Report 2016. http://www.digitalnewsreport.org/, luettu 27.6.2016. 
Ruotsalainen, Juho \& Heinonen, Sirkka (2015). Media ecology and the future ecosystemic society. European Journal of Futures Research, 3:9,1-10.

Rutenberg, Jim (2016). A 'Dewey defeats Truman' lesson for the digital age. The New York Times, 9.11. 2016.

Schudson, Michael (2001). The objectivity norm in american journalism. Journalism, 2:2, 149-170.

Soffer, Oren (2012). Liquid language? On the personalization of discourse in the digital era. New media $Q$ society, 14:7, 1092-1110, DOI: 10.1177/1461444812439550

Soffer, Oren (2009). The competing ideals of objectivity and dialogue in American journalism. Journalism, 10:4, 473-491, DOI: 10.1177/1464884909104950

Steensen, Steen (2009). Online feature journalism. Journalism Practice, 3:1, 13-29, DOI: $10.1080 / 17512780802560716$

Tandoc, Edson C. Jr. (2014). Journalism is twerking? How web analytics is changing the process of gatekeeping. New Media Q Society, 16:4, 559-575, DOI: 10.1177/1461444814530541

Tandoc, Edson C. Jr. \& Jenkins, Joy (2015). The buzzfeedication of journalism? How traditional news organizations are talking about a new entrant to the journalistic field will surprise you! Journalism, 1-19, DOI: 10.1177/1464884915620269

Tandoc, Edson C. Jr. \& Vos, Tim P. (2015). The journalist is marketing the news. Journalism Practice, DOI: $10.1080 / 17512786.2015 .1087811$

Tapscott, Don (1998). Growing Up Digital. The Rise of the Net Generation. New York: McGraw-Hill.

Tien Vu, Hong (2014). The online audience as gatekeeper: The influence of reader metrics on news editorial selection. Journalism, 15:8:, 1094-1110, DOI: 10.1177/1464884913504259

Tiffen, R., Jones P.K., Rowe, D., ym. (2014). Sources in the news: a comparative study. Journalism Studies, $15: 4,374-391$.

Wahl-jorgensen, Karin (2013). Subjectivity and story-telling in journalism. Examining expressions of affect, judgement and appreciation in Pulitzer Prize-winning stories. Journalism Studies, 14:3, 305-320.

Wahl-Jorgensen, K.; Berry, M.; Garcia-Blanko, I.; Bennett, L. \& Cable, J. (2016). Rethinking balance and impartiality in journalism? How the BBC attempted and failed to change the paradigm. Journalism, 1-20. DOI: 10.1177/1464884916648094.

Welbers, K.; Atteveldt, W. van; Kleinnijenhuis, J.; Ruigrok, N. \& Schaper, J. (2015). News selection criteria in the digital age: Professional norms versus online audience metrics. Journalism, 1-17, DOI: $10.1177 / 1464884915595474$.

Zoonen, Liesbet van (2012). I-Pistemology: Changing truth claims in popular and political culture. European Journal of Communication, 27:1, 56-67, DOI: 10.1177/0267323112438808

Zoonen, Liesbet van (1998). A professional, unreliable, heroic marionette (M/F): Structure, agency and subjectivity in contemporary journalisms. European Journal of Cultural Studies, 1(1): 123-43.

Zdovc, Sonja M. (2007). The use of novelistic techniques in Slovene journalism. Journalism Studies, 8:2, 248263, DOI: $10.1080 / 14616700601148853$

\section{Liite 1}

Aineistossa mukana olevat mediat ja niiden about-sivujen URL-osoitteet:

Aeon (http://aeon.co/magazine/about/), All Things Digital (http://allthingsd.com/about/site), Bleacher Report (http://bleacherreport.com/about), Business Insider (http://businessinsider.com/about), Buzzfeed (http://www.buzzfeed.com/about), De Correspondent (https://decorrespondent.nl/en), First Look Media (https://firstlook.org/about), Flavorwire (http://flavorwire.com/about/), Gawker (gawker.com/about), Gigaom (about.gigaom.com), GlobalPost (http://www.globalpost.com/content/about), Mashable (http:// mashable.com/about), Mic (http://mic.com/about), MinnPost (http://www.minnpost.com/about), n+1 (https://nplusonemag.com/about), National Public Radio (http://www.npr.org/about/aboutnpr), News Deeply (http://www.newsdeeply.com/overview/), OzY (http://www.ozy.com/about/), Politico (http://www. politico.com/about/our-story), ProPublica (http://www.propublica.org/about/), Quartz (http://qz.com/ about/welcome-to-quartz), Re/code (http://recode.net/about), Rookie (http://www.rookiemag.com/ us), Salon (http://www.salon.com/about/), Talking Points Memo (http://talkingpointsmemo.com/about), TechCrunch (http:// techcrunch.com/about), The Awl (http://www.theawl.com/about), The Daily Beast (http://www.thedailybeast.com/company/about-us.html), The Daily Caller (http://dailycaller.com/about-us), The Marshall Project (https://www.themarshallproject.org/about), The New Inquiry (http://thenewinquiry. com/about/), The Texas Tribune (http://www.texastribune.org/about), The Verge (http://www.theverge. com/about-the-verge), The Rumpus (http://therumpus.net/about/), Thought Catalog (http://thoughtcatalog. com/about/), Vox (http://www.voxmedia.com/brands/vox). 